\title{
TNF- $\alpha$ Drives the CCL4 Expression in Human Monocytic Cells: Involvement of the SAPK/JNK and NF-kB Signaling Pathways
}

\author{
Rasheed Ahmad ${ }^{a}$ Shihab Kochumon ${ }^{a}$ Betty Chandy ${ }^{b}$ Steve Shenouda \\ Merin Koshy ${ }^{a} \quad$ Amal Hasan ${ }^{a} \quad$ Hossein Arefanian ${ }^{a} \quad$ Fahd Al-Mulla $^{c}$ Sardar Sindhu ${ }^{d}$ \\ almmunology Unit, Dasman Diabetes Institute, Kuwait City, Kuwait, 'basman Biobank Core Facility, \\ Dasman Diabetes Institute, Kuwait City, Kuwait, 'Functional Genomics Unit, Dasman Diabetes Institute, \\ Kuwait City, Kuwait, 'Animal and Zebrafish Core Facility, Dasman Diabetes Institute, Kuwait City, Kuwait
}

\section{Key Words}

TNF- $\alpha \cdot \mathrm{CCL} 4 / \mathrm{MIP}-1 \beta \cdot \mathrm{THP}-1 \cdot \mathrm{SAPK} / \mathrm{JNK} \cdot \mathrm{NF}-\mathrm{KB} \cdot$ Inflammation

\begin{abstract}
Background/Aims: Increased circulatory levels of both TNF- $\alpha$ and CCL4/MIP-1 $\beta$ are found in metabolic diseases. However, it is unclear whether TNF- $\alpha$ which is a signature proinflammatory cytokine involved in metabolic inflammation, can induce/promote the expression of CCL4. Methods: THP-1 human monocytic cells and THP-1-derived macrophages were stimulated with TNF- $\alpha$ and LPS-treatment as a positive control. CCL4 mRNA/protein expression was measured using qRT-PCR/ELISA, respectively. Stress-activated protein kinases (SAPK)/ c-Jun $\mathrm{N}$-terminal kinase (JNK) activity was determined using the assay kit. Mechanistic pathways were studied using anti-TNFR1/2 antibodies, pharmacological inhibitors, siRNAs, and NF-KB/AP-1 reporter-expressing THP-1-XBlue cells. Phosphorylation of signaling molecules was assessed by Western blotting. Results: TNF- $\alpha$ induces CCL4 expression at mRNA and protein levels, in both THP-1 monocytic cells and macrophages $(P<0.05)$. TNF- $\alpha$-driven CCL4 production was markedly abrogated by pre-treatment with anti-TNFR1/2 neutralizing antibodies. TNF- $\alpha$ treatment induced phosphorylation of SAPK/JNK, c-Jun, and NF-KB. Genetic and/or pharmacologic inhibition of SAPK/JNK and NF-KB pathways suppressed the TNF- $\alpha$-induced $C C L 4$ expression $(P<0.05)$. NF-KB/AP-1 activity was found to be significantly increased in TNF$\alpha$-treated SEAP reporter-expressing monocytic cells. Conclusion: These data suggest that TNF- $\alpha$ drives CCL4 expression in THP-1 monocytic cells/macrophages via the activation of SAPK/JNK and NF-KB pathways. The findings may provide new insights into understanding the regulatory role of TNF- $\alpha$ in augmenting CCL4 expression during inflammatory conditions.




\section{Cellular Physiology Cell Physiol Biochem 2019;52:908-921 \\ \begin{tabular}{ll|l} 
and Biochemisty $10.33594 / 000000063$ & (c) 2019 The Author(s). Published by \\
Cell Physiol Biochem Press GmbH\&Co. KG
\end{tabular} \\ Ahmad et al.: TNF- $\alpha$ Induces CCL4}

\section{Introduction}

Chemokine CC motif ligand 4 (CCL4) belongs to the CC chemokine family and is also known as macrophage inflammatory protein (MIP)-1 $\beta$. CCL4 is a chemoattractant for various cell types including macrophages, natural killer cells, monocytes, immature dendritic cells, and coronary endothelial cells [1-5]. Several studies have pointed to the association between CCL4 and pathogenesis of a plethora of morbid conditions implicating inflammation as the underlying factor such as psoriasis vulgaris [6], sarcoidosis [7], cystic fibrosis [8], multiple sclerosis [9], systemic lupus erythematosus [10], obesity-associated metabolic inflammation [11], prediabetes [12], type-1 diabetes (T1D) [13], type-2 diabetes (T2D) [14], stroke [15], acute coronary syndrome [16], and atherosclerosis [17].

Low-grade chronic inflammation known as a metabolic inflammation plays a pivotal role in the development of insulin resistance and T2D and its complications involving atherosclerosis and hepatic steatosis. In obesity/T2D, adipose tissue is marked by infiltration of major immune regulatory cells, especially proinflammatory M1 macrophages, followed by increased production of inflammatory cytokines/chemokines. Proinflammatory macrophage accumulation in the adipose tissue is an important feature of increasing obesity which correlates with local expression of signature inflammatory proteins in this compartment $[18,19]$. These inflammatory mediators, including CCL4, contribute at various levels to the infiltration and/or activation of monocytes/macrophages into the adipose tissue and set stage for further aggravation of metabolic inflammation [20,21]. CCL4 is regarded as one of the major macrophage attractants and its link with T1D and T2D may be explained by the critical role of macrophages in the destruction of beta cells, development of insulin resistance, and progression of prediabetes status to fulminating T1D and T2D [13, 14, 22]. Increased circulatory levels of CCL4 were reported in high-risk individuals that later progressed to T1D [12]. Likewise, elevated CCL4 levels in the circulation of individuals with obesity and T2D were documented [23, 24]; however, much less work has been done regarding the CCL4 production and regulation.

Immunometabolic changes in obesity and T2D lead to the increased production of proinflammatory cytokine TNF- $\alpha$ and several chemokines [25-27]. Therefore, a plausible mechanistic link between TNF- $\alpha$ and chemokines in metabolic disease has been envisaged. TNF- $\alpha$ is a proinflammatory cytokine that can regulate a wide range of cellular and biological processes including inflammation and immunomodulation, cell proliferation and differentiation, growth inhibition, apoptosis, angiogenesis, and energy metabolism [28]. TNF- $\alpha$ is produced by different cell types such as monocytes/macrophages, T-lymphocytes, smooth muscle cells, adipocytes, and fibroblasts [29-31]. TNF- $\alpha$ exerts its biological effect through its transmembrane glycoprotein receptors known as TNF- $\alpha$ receptor 1 (TNFR1) and TNF- $\alpha$ receptor 2 (TNFR2); however, TNF- $\alpha$ binds to TNFR1 with high affinity $[32,33]$. TNF $\alpha$ binding with its surface receptors engages multiple signal transduction pathways including three groups of mitogen-activated protein (MAP) kinases i.e. extracellular signal-regulated kinases (ERKs), c-Jun NH2-terminal kinases (JNKs) and p38 MAP kinases. Signaling through MAP kinase pathways induces secondary response by increasing expression of several inflammatory cytokines including TNF- $\alpha[34,35]$.

The association between TNF- $\alpha$ and obesity/T2D is well established. TNF- $\alpha$ play a role in the development of insulin resistance and a strong correlation was reported between circulatory levels of TNF- $\alpha$ and reduced insulin-stimulated glucose disposal [31, 36-42]. Increased adipose tissue levels of both mTNF- $\alpha$ and STNF- $\alpha$ were found in obese/T2D patients $[43,44]$. Although, TNF- $\alpha$ is known to induce inflammatory mediators such as IL-1 $\beta$, IL-6, and IL-8, its role in CCL4 induction remains unclear. Based on the premise that TNF- $\alpha$ and CCL4 are consistently found to be elevated in several inflammatory conditions, we hypothesized that TNF- $\alpha$ could induce CCL 4 expression in monocytic cells and macrophages. Herein, we present the evidence that TNF- $\alpha$ upregulates the expression of CCL4 in human monocytes through the mechanism that involves SAPK/JNK and NF-kB mediated signaling. 


\section{Cellular Physiology and Biochemistry}

Cell Physiol Biochem 2019;52:908-921

\begin{tabular}{l|l}
\hline DOI: $10.33594 / 000000063$ & (c) 2019 The Author(s). Published by
\end{tabular}

Ahmad et al.: TNF- $\alpha$ Induces CCL4

\section{Materials and Methods}

\section{Reagents and Cell lines}

Recombinant human TNF- $\alpha$ (Catalog number: 210-TA-100), anti-hs TNF-R1 (Catalog number: MAB625), anti-hs TNF-RII (Catalog number: MAB726) and Mouse IgG1 (Catalog number: MAB0026) were purchased from R\&D Systems (Minneapolis, USA). LPS (Catalog number: L43391), Resveratrol (Catalog number: R5010), Triptolide (Catalog number: T3652), Palmitate (Catalog number: P5585), PMA (Catalog number: P1585) were purchased from Sigma (San Diego, CA). SP600125 (Catalog number: 8177), SB203580 (Catalog number:5633), PD98059(Catalog number: 9900), U0126 (Catalog number: 9903), Cell Lysis Buffer (Catalog number: 9803), LY294002, (Catalog number: 9901) and Wortmannin (Catalog number: 9951), anti p-SAPK/JNK (Catalog number: 9251S), anti p-c-Jun (Catalog number: 9261L), anti pNF- $\mathrm{BB}$ (Catalog number: 3031S), anti SAPK/JNK (Catalog number: 9252S0), anti c-Jun (Catalog number: 9165S) and anti NF-кB (Catalog number: 3034S) antibodies were purchased from Cell Signaling, USA. SAPK/JNK siRNA (Assay ID: s11152,), Negative siRNA (Catalog number: 4390843), CCL4 TaqMan Assays (Assay ID: Hs99999148_ml), SAPK/JNK TaqMan Assay (Assay ID: Hs01548508_m1) and GAPDH (Assay ID: Hs03929097_g1) were purchased from Thermo Scientific, USA.

Human monocytic leukemia cell line THP-1 was purchased from American Type Culture Collection. THP1 X-Blue cells stably expressing a secreted embryonic alkaline phosphatase (SEAP) reporter inducible by NF-kB and AP-1 were purchased from InvivoGen (San Diego, CA, USA). Quanti-Blue solution (rep-qbs), Zeocin (Catalog number: ant-zn-1), and Normocin (Catalog number: ant-nr-1) were also purchased from Invivogen. RPMI-1640 culture Medium (Catalog number: A1049101), HI-FBS (Catalog number: 16140071), L-Glutamine (Catalog number: 25030-081), Penicillin-Streptomycin (Catalog number: 15140-122) were purchased from Gibco, Invitrogen, Grand Island, NY, USA.

\section{Cell Culture}

Monocytic THP-1 cells were grown in RPMI-1640 culture medium supplemented with 10\% fetal bovine serum, $2 \mathrm{mM}$ glutamine, $1 \mathrm{mM}$ sodium pyruvate, $10 \mathrm{mM} \mathrm{HEPES,} 100 \mathrm{ug} / \mathrm{ml}$ normocin, $50 \mathrm{U} / \mathrm{ml}$ penicillin and $50 \mu \mathrm{g} / \mathrm{ml}$ streptomycin, and incubated at $37^{\circ} \mathrm{C}$ (with humidity) in $5 \%$ CO2. THP-1-XBlue cells were cultured in complete RPMI-1640 medium with the addition of selective antibiotic zeocin $(200 \mu \mathrm{g} / \mathrm{ml}$; InvivoGen, San Diego, CA, USA). Prior to stimulation, THP-1 cells were transferred into growth medium.

\section{Cell stimulation}

Monocytic cells were cultured in 12-well plates (Costar, Corning Incorporated, Corning, NY, USA) at $1 \times$ $10^{6}$ cells/well concentration unless indicated otherwise. Cells were stimulated with $\mathrm{rhTNF}-\alpha(10 \mathrm{ng} / \mathrm{ml}) \mathrm{or}$ LPS $(10 \mathrm{ng} / \mathrm{ml})$ for $24 \mathrm{hrs}$ at $37^{\circ} \mathrm{C}$. Cells were harvested for RNA isolation and culture media were collected for measuring CCL4/MIP-1 $\beta$ secretion.

\section{Macrophage differentiation}

THP1 cells were plated in 12 well plate at $1 \times 10^{6}$ cells $/ \mathrm{ml}$ concentration and treated with PMA (50 ng/ $\mathrm{ml}$ ) for 72 hours at $37^{\circ} \mathrm{C}$. Cells were washed, fresh culture medium was added and differentiated macrophages were incubated for another 24 hours [45]. Then, differentiated macrophages were stimulated with TNF- $\alpha$ (10ng/ml; Sigma, San Diego, CA, USA) or LPS (10 ng/ml; Sigma, Saint Louis, MO, USA) for $24 \mathrm{hrs}$ at $37^{\circ} \mathrm{C}$. Cells were harvested for RNA isolation and culture media were collected for measuring CCL4 secretion by ELISA.

\section{TNF- $\alpha$ receptor Neutralization}

THP- 1 cells were plated in a 12 well plate at a concentration of $1 \times 10^{6}$ cells $/ \mathrm{ml}$ and treated separately with $2 \mu \mathrm{g} / \mathrm{ml}$ of neutralizing TNF-R1 mAb, TNF-R2 mAb or Isotype-matched IgG1 control for 40 minutes. Antibody-treated cells were treated with TNF- $\alpha$ and incubated for 24 hrs. Collected cells and supernatant were subjected for CCL4 expression analysis using qRT-PCR and ELISA. 


\section{Cellular Physiology Cell Physiol Biochem 2019;52:908-921

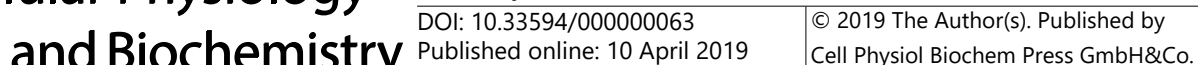 \\ Ahmad et al.: TNF- $\alpha$ Induces CCL4}

Measurement of NF- $\kappa B / A P-1$ activity

THP-1-XBlue cells are THP-1 cells transfected with a reporter construct, expressing a secreted embryonic alkaline phosphatase (SEAP) gene under the control of a promoter inducible by the transcription factors NF- $\mathrm{KB}$ and AP-1. Upon stimulation, NF- $\mathrm{\kappa B}$ and AP-1 are activated and subsequently secreted SEAP. THP-1 XBlue cells were stimulated with TNF- $\alpha(10 \mathrm{ng} / \mathrm{ml})$ or LPS $(10 \mathrm{ng} / \mathrm{ml}$; positive control) for $24 \mathrm{hrs}$ at $37^{\circ} \mathrm{C}$. Levels of SEAP were detected in the culture media after $3 \mathrm{hrs}$ incubation of supernatants with QuantiBlue solution at $650 \mathrm{~nm}$ wave length by ELISA reader.

\section{Small interfering RNA (siRNA) transfections}

For transient transfection, THP- 1 cells ( $1 \times 10^{6}$ cells) were resuspended in $100 \mathrm{ul}$ of nucleofector solution provided with the Amaxa Nuclecfector Kit $\mathrm{V}$ and transfected separately with SAPK/JNK siRNA, Negative Control siRNA and pmaxGFP plasmid ( 0.5 ug; Amaxa Nuclecfector Kit V for THP-1, Lonza). All transfection experiments were performed with Amaxa Cell Line Nucleofector Kit V for THP-1 (Lonza, Germany) by using Amaxa Electroporation System (Amaxa Inc, Germany). After $36 \mathrm{hrs}$ transfection, cells were treated with TNF- $\alpha(10 \mathrm{ng} / \mathrm{ml})$ for $24 \mathrm{hrs}$. Cells were harvested for RNA isolation and culture media were collected for measuring CCL4 secretion. SiRNA Transfection efficiency was analyzed by fluorescence microscopy and SAPK/JNK gene Knock down level was assessed by Real Time-PCR using SAPK/JNK Taqman assays.

\section{Real Time RT-PCR}

Total RNA was extracted from treated and untreated THP1 cells using RNeasy Mini Kit (Qiagen, Valencia. CA, USA). One microgram of total RNA was used for cDNA conversion using high capacity cDNA reverse transcription kit (Applied Biosystems, Foster city, CA, USA). Real time polymerase chain reaction was performed using 50ng of cDNA, gene specific TaqMan Gene Expression Assays containing gene-specific primers and TaqMan MGB probe (6-FAM dye-labeled) and TaqMan ${ }^{\circledR}$ Gene Expression Master Mix (Applied Biosystems, Foster city, CA, USA) in a QuantStudio 5Fast Real-Time PCR System (Applied Biosystems, Foster City, CA, USA). The Ct values of CCL4 and SAPK/JNK were normalized with corresponding GAPDH Ct values and the expression level of CCL4 in treated samples relative to control samples were calculated with $-2 \Delta \Delta \mathrm{Ct}$-method. Relative mRNA expression was expressed as fold expression over average of control gene expression. The expression level in control treatment was assumed to be 1 .

\section{SAPK/JNK Kinase Assay}

SAPK/JNK kinase activity was performed using SAPK/JNK Kinase assay kit (Cell Signaling, USA) according to the manufacturer's instructions. Cell lysates were prepared using lysis buffer from THP-1 cells treated with TNF- $\alpha$ and palmitate (200uM; a positive control) and untreated controls. Immunoprecipitation of phospho SAPK/JNK was done using immobilized phospho-SAPK/JNK rabbit mAb linked to agarose beads to pull down SAPK/JNK kinases from cell extracts. The immunoprecipitated SAPK/JNK extract was incubated with c-Jun fusion protein, kinase buffer and ATP. c-Jun phosphorylation mediated by SAPK/JNK kinase was measured by immunoblotting using phospho c-Jun antibody.

\section{Secreted CCL4 quantification}

Secreted CCL4 protein in supernatants of monocytic cells stimulated with TNF- $\alpha$ or LPS was quantified using sandwich ELISA following the manufacturer's instructions (R\&D systems, Minneapolis, USA).

\section{Western blotting}

THP- 1 cells treated with TNF- $\alpha$ at different time points were harvested and incubated for $30 \mathrm{~min}$ with lysis buffer. The lysates were centrifuged at $14000 \mathrm{~g}$ for $10 \mathrm{~min}$ and the supernatants were collected. Protein concentration was measured by Quickstart Bradford Dye Reagent, 1x Protein Assay kit (Bio-Rad Laboratories, Inc, CA). Protein $(20 \mu \mathrm{g})$ samples were mixed with loading buffer, heated for $5 \mathrm{~min}$ at $95^{\circ} \mathrm{C}$ and resolved by $12 \%$ SDS-PAGE. Cellular proteins were transferred to Immuno-Blot PVDF membrane (BioRad Laboratories, USA) by electro blotting. The membranes were blocked with 5\% non-fat milk in PBS for $1 \mathrm{~h}$, followed by incubation with primary antibodies against SAPK/JNK, p-SAPK/JNK, c-Jun, p-c-Jun, NF- $\mathrm{kB}$ and p- NF- $\kappa B$ in 1:1000 dilution at $4^{\circ} \mathrm{C}$ overnight. The blots were then washed three times with TBS-T and 
incubated for $2 \mathrm{hrs}$ with HRP-conjugated secondary antibody (Promega, Madison, WI, USA). Immunoreactive bands were developed using an Amersham ECL Plus Western Blotting Detection System (GE Health Care, Buckinghamshire, UK) and visualized by Molecular Imager ${ }^{\circledR}$ VersaDoc ${ }^{\mathrm{TM}}$ MP Imaging Systems (Bio-Rad Laboratories, Hercules, CA, USA).

\section{Statistical analysis}

Statistical analysis was performed using GraphPad Prism software (La Jolla, CA, USA). Data are shown as mean \pm standard error mean, unless otherwise indicated. One-way ANOVA was used to compare group means with that of control group. For all analyses, $\mathrm{P}$ value $<0.05$ was considered significant $\left({ }^{*}\right), \mathrm{P}<0.01$ as highly significant $\left({ }^{* *}\right)$, and $\mathrm{P}<0.001 / \mathrm{P}<0.0001$ were considered as extremely significant $\left({ }^{* * *} /{ }^{* * * *}\right)$.

\section{Results}

TNF- $\alpha$ induces expression ofCCL4 in THP-1 human monocytic cells and derived macrophages

Increased circulating levels of both TNF- $\alpha$ and CCL 4 have been reported in Obesity and T2D [46]. Therefore, we asked if TNF- $\alpha$ could induce the expression of CCL4 in human monocytic cells as well as monocyte-derived macrophages. Our data show that CCL4 mRNA expression was significantly upregulated in TNF- $\alpha$-treated THP-1 monocytic cells $(69.5 \pm 3.5$ fold; $\mathrm{P}=0.0026)$ and THP-1-derived macrophages ( $112.00 \pm 9.00$ fold; $\mathrm{P}=0.0065)$ compared to controls (Fig. 1A and C). In agreement with elevated CCL4 gene expression, CCL4 secretory protein levels were also significantly higher in supernatants from TNF- $\alpha$-treated THP1 monocytic cells $(277.8 \pm 13.53 \mathrm{pg} / \mathrm{ml} ; \mathrm{P}=0.0025)$ and monocyte-derived macrophages (359.7 $\pm 16.8 \mathrm{pg} / \mathrm{ml} ; \mathrm{P}=0.0022$ ) compared to controls (Fig. 1B and D).

Fig. 1. TNF- $\alpha$ upregulates CCL4 expression in human monocytic cells and derived macrophages. THP-1 cells were treated with TNF- $\alpha$ (10 ng/ml) or LPS (10ng/ml; positive control) for $24 \mathrm{hrs}$. Cells and culture media were collected. Total RNA was isolated and CCL4 mRNA was quantified by realtime RT-PCR. Relative mRNA expression was expressed as fold change over average gene expression in mock-treated controls. Secreted CCL4 protein was measured in cell supernatants using ELISA. To use THP1 derived macrophages, THP-1 monocytic cells were differentiated into macrophages with PMA (50 ng/ml) for 72 hours and then treated with TNF- $\alpha$ and LPS for $24 \mathrm{hrs}$ as described earlier. Cells and culture media were collected. CCL4 mRNA expression in cell lysates and secreted CCL4 protein in cell supernatants were measured as described. The data show that CCL4 (A) gene $(\mathrm{P}=0.0026)$ and $(\mathrm{B})$ protein $(\mathrm{P}=0.0025)$ expression was significantly higher in THP-1 monocytic cells treated with TNF- $\alpha$ compared to controls. Similarly, CCL4 (C) gene $(\mathrm{P}=0.0065)$ and $(\mathrm{D})$ protein $(\mathrm{P}=0.0022)$ expression was significantly upregulation in THP-1-derived TNF- $\alpha$-treated macrophages

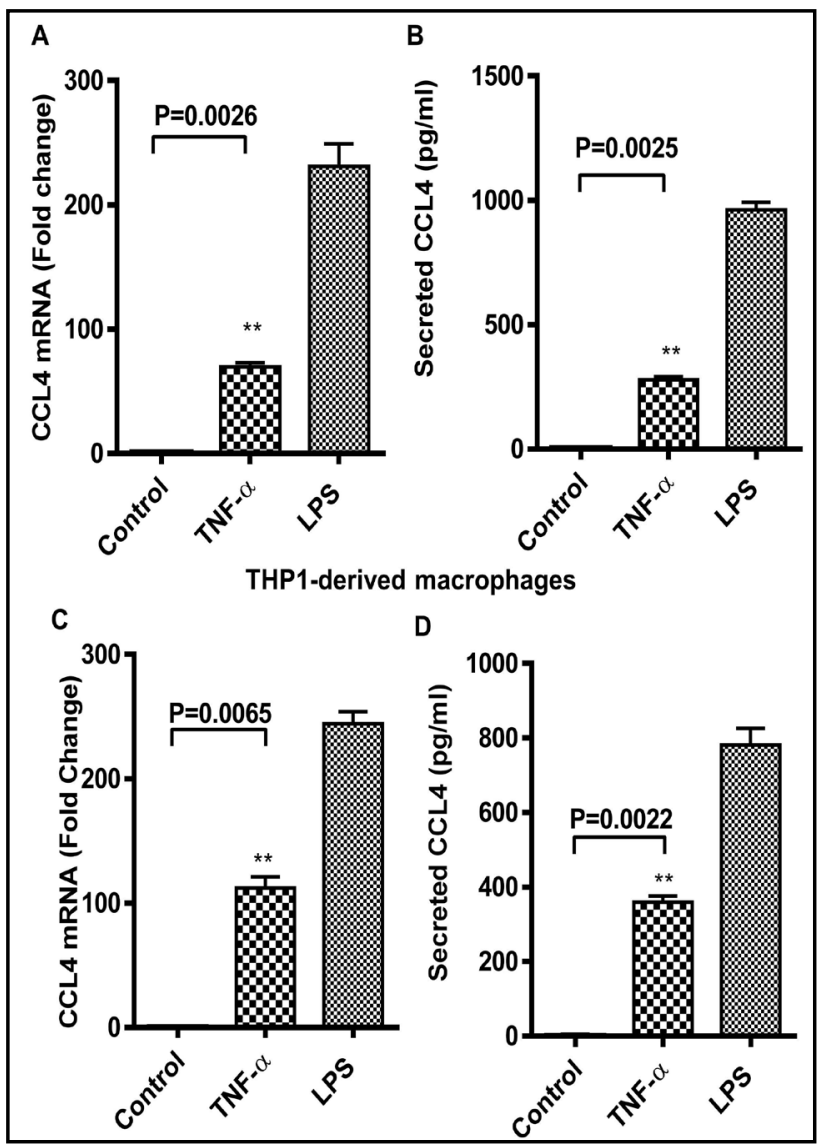
compared to controls. 
Fig. 2. Neutralization of the TNFR1 and TNFR2 receptors suppresses TNF- $\alpha$-induced CCL4 expression. THP-1 monocytic cells were pre-treated with $2 \mu \mathrm{g} / \mathrm{mL}$ of anti-TNFR1/2 neutralizing antibodies or isotype-matched IgG1 control antibody and incubated at $37^{\circ} \mathrm{C}$ for $40 \mathrm{~min}$. Later, cells were stimulated with TNF- $\alpha(10 \mathrm{ng} / \mathrm{ml})$ and incubated for $24 \mathrm{hrs}$. Cells and culture media were collected and CCL4 mRNA in cell lysates and protein expression in cell supernatants were determined using realtime RT-PCR and ELISA, respectively. The data show that CCL4 (A) gene (TNFR1 Ab: $\mathrm{P}=0.0004$; TNFR2 $\mathrm{Ab}: \mathrm{P}=0.0005)$ and $(\mathrm{B})$ secreted protein (TNFR1 Ab: $\mathrm{P}=0.0002$; TNFR2 Ab: $\mathrm{P}=0.0002$ ) expression was significantly reduced in monocytic cells that were pre-treated with either TNFR1 or TNFR2 specific neutralizing antibodies compared to isotype control antibody treated cells.

TNF- $\alpha$-induced CCL4 expression involves TNF-R1 and TNF-R2 receptor mediated signaling

TNF-R1 and TNF-R2 are the membrane spanning receptors for TNF- $\alpha$. Next, we wanted to assess if TNF$\alpha$-induced CCL4 expression in monocytic cells was dependent on binding of TNF- $\alpha$ to both TNF-R1 and TNF-R2 cognate receptors. To this end, we employed neutralizing antibodies against TNF-R1 and TNF-R2 receptors along with isotype control antibody to block receptors prior to stimulating cells with TNF- $\alpha$. Our data show that TNF-R1 and TNF-R2 receptor masking by cognate antibodies significantly abrogated TNF$\alpha$-induced CCL4 expression in THP1 cells at both mRNA (TNF-R1: $18 \pm 2$ fold; $\mathrm{P}=0.0004$, TNF-R2: $24 \pm 1$ fold; $\mathrm{P}=0.0005$, Fig. $2 \mathrm{~A}$ ) and protein levels (TNF-R1: $37.2 \pm 3.3 \mathrm{pg} / \mathrm{ml} ; \mathrm{P}=0.0002$, TNF-R2: $69.5 \pm 3.5 \mathrm{pg} / \mathrm{ml}$; $\mathrm{P}=0.0002$, Fig. 2B).

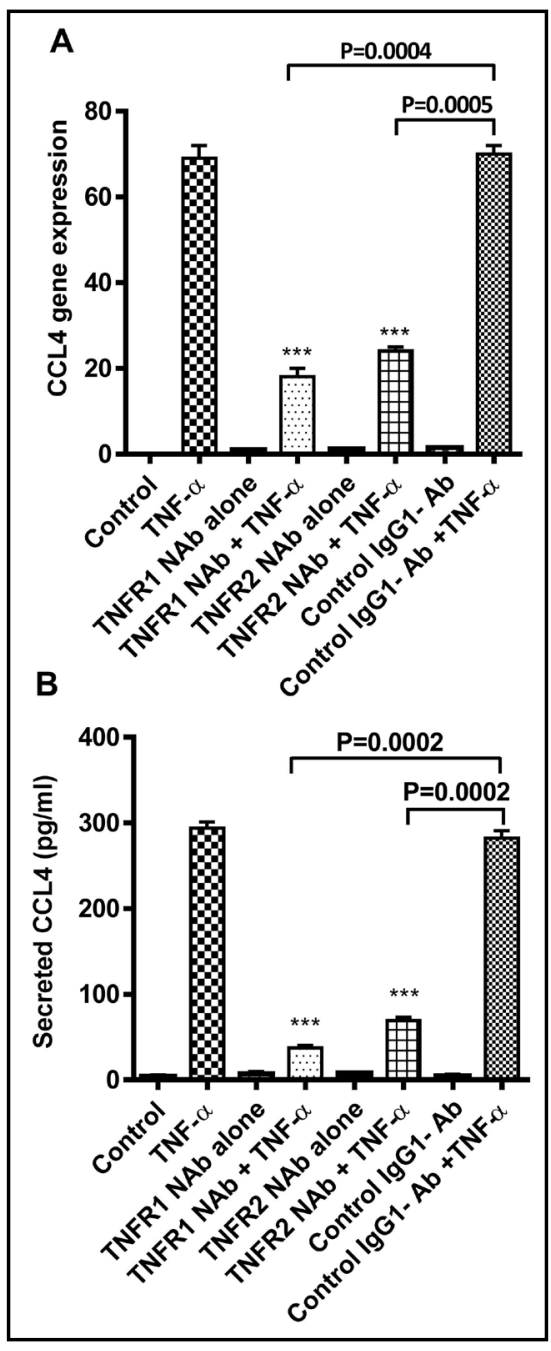

TNF- $\alpha$-induced CCL4 expression in THP-1 monocytic cells and derived macrophages involves SAPK/JNK and $N F-\kappa B$ signaling pathways

Binding of TNF- $\alpha$ with its receptors TNF-R1 or TNF-RII is followed by conformational changes leading to activation of a downstream signaling cascade of MAPK and NF- $\kappa B$ pathways. We next investigated whether these pathways were involved in TNF- $\alpha$-induced CCL4 expression in THP-1 cells. To this effect, both pharmacological inhibitors and genetic suppression were used for cell treatment before exposure to TNF- $\alpha$ while mock treatments with vehicle or scrambled siRNAs served as controls. The data show that CCL4 mRNA expression was significantly abrogated by treatment with the inhibitor of SAPK/JNK (SP600125) $(14 \pm 1.22$ fold; $\mathrm{P}<0.05)$ but not with inhibitors of MAPK (PD98059 and U0126) and p38 (SB203580) (Fig. 3A). Consistent with CCL4 gene suppression, TNF- $\alpha$-induced CCL4 protein levels were also significantly reduced in supernatants of THP-1 cells pretreated with SAPK/JNK inhibitor SP600125 (50.64 \pm 0.42 pg/ml; P < 0.05; Fig. 3B). Our data further show that TNF- $\alpha$ treatment increases phosphorylation of SAPK/JNK and c-Jun (Fig. 3C). Next, to validate the results of chemical inhibition, cells were transfected with SAPK/JNK siRNA and target gene knock down efficiency was assessed by SAPK/JNK TaqMan RT-PCR assays. The siRNA transfection resulted in significant suppression of SAPK/JNK mRNA expression in THP-1 monocytic cells $(0.39 \pm 0.03$ fold $)$ compared to mock transfected control $(\mathrm{P}=0.0024$; Fig. 4A). Next, the data show significant downmodulation of CCL4 mRNA expression $(69 \pm 3.0$ fold; $\mathrm{P}=0.0108$; Fig. 4B) and protein secretion (352.1 \pm 14.64 ; $\mathrm{P}=0.015$; Fig. 4C) in SAPK/ 
Fig. 3. TNF- $\alpha$-induced CCL4 expression is abrogated by treatment with chemical inhibitor of SAPK/JNK pathways. THP-1 monocytic cells were pretreated with chemical inhibitors of MAPK (U0126, PD98059), p38 (SB203580) or SAPK/ JNK (SP600125) pathways using concentrations as recommended by the manufacturer and cells were incubated at $37^{\circ} \mathrm{C}$ for $1 \mathrm{hr}$. Later, cells were stimulated with TNF- $\alpha$ $(10 \mathrm{ng} / \mathrm{ml})$ and incubated for $24 \mathrm{hrs}$. Cells and culture media were collected and CCL4 mRNA in cell lysates and protein expression in cell supernatants were determined using real-time RT-PCR and ELISA, respectively. The

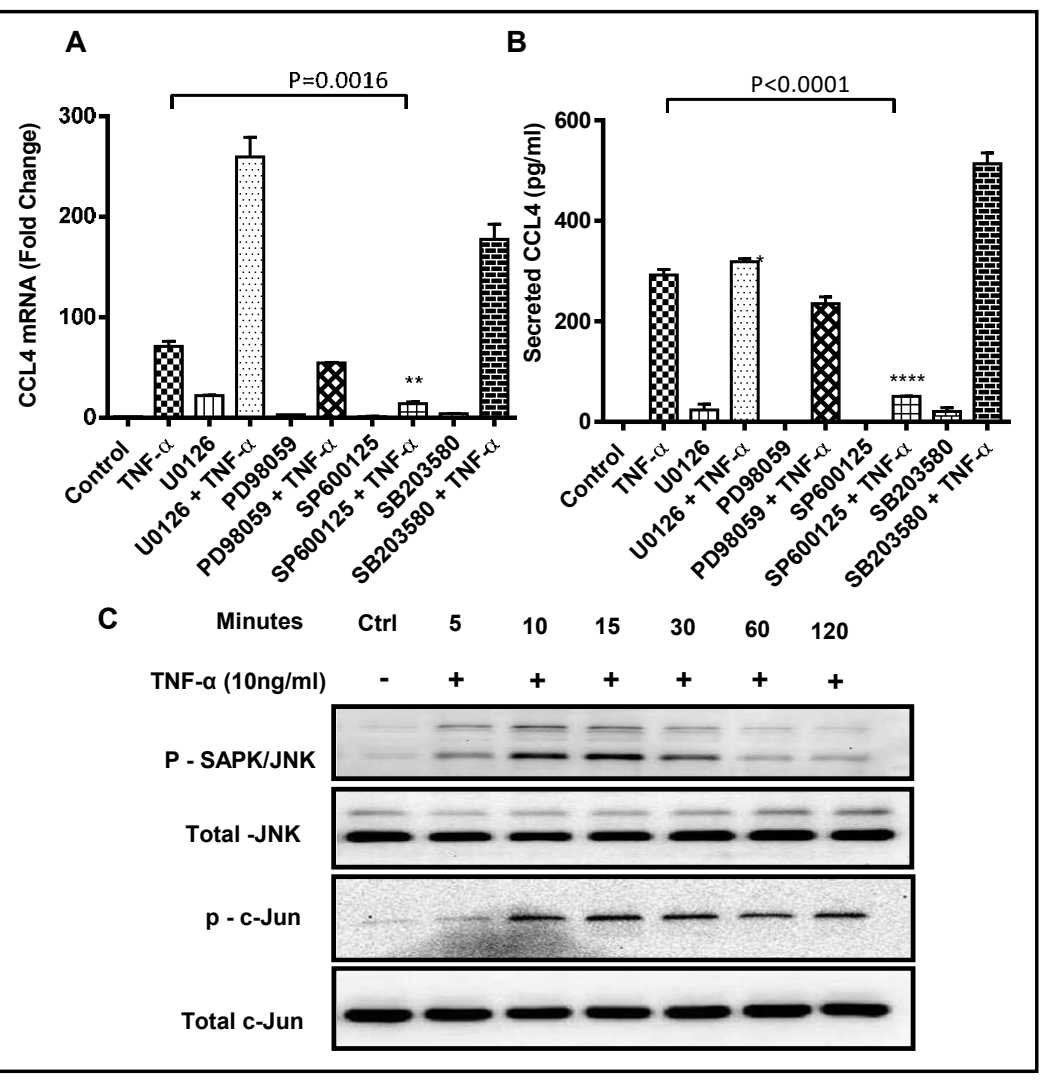
data show that CCL4 (A) gene $(\mathrm{P}=0.0081)$ and $(\mathrm{B})$ secreted protein $(\mathrm{P}=0.0021)$ expression were significantly suppressed in cells pretreated with SAPK/JNK pathway inhibitor SP600125 compared to mock-treated controls. However, no significant suppression was observed with MAPK and p38 inhibitors. To analyze TNF- $\alpha$-induced protein phosphorylation, cells were incubated with TNF- $\alpha(10 \mathrm{ng} / \mathrm{ml})$ and cell samples were collected at 5, 10, 15, 30, 60, and 120 min. Mock treated cells served as control. Cell lysates in RIPA buffer were calibrated for protein concentration, resolved by SDS-PAGE and SAPK/JNK and c-Jun protein phosphorylation was determined using specific antibodies against phosphorylated and total proteins. (C) The data show that TNF- $\alpha$ treatment of THP-1 human monocytic cells induces phosphorylation of SAPK/JNK as well as c-Jun.

JNK siRNA-transfected THP1 cells treated with TNF- $\alpha$ compared to mock treated controls. To further confirm the role of SAPK/JNK and c-Jun in TNF- $\alpha$ induced CCL4 induction, SAPK/ JNK Kinase assay was performed and the data show SAPK/JNK kinase activity with increased c-Jun phosphorylation in TNF- $\alpha$ treated cells compared to mock treated controls (Fig. 4D). Treatment with palmitate, a known inducer of SAPK/JNK kinase activity [45], was used as a positive control in the assay for comparison with TNF- $\alpha$ treatment.

TNF- $\alpha$ is known to act through the activation of NF- $\kappa B$ pathway leading to the release of inflammatory mediator CCL2 [47]. In the present study, we also used NF- $\kappa B$ inhibitors triptolide and resveratrol for cell treatment before TNF- $\alpha$ treatment and found that both triptolide and resveratrol pre-treatments suppressed the expression of CCL4 mRNA (Triptolide: $21.58 \pm 2.86$ fold, $\mathrm{P}<0.0001$; Resveratrol: $27.23 \pm 1.60$ fold, $\mathrm{P}<0.0001$; Fig. $5 \mathrm{~A}$ ) and CCL4 protein (Triptolide: $23.0 \pm 1.30 \mathrm{pg} / \mathrm{ml}, \mathrm{P}<0.0001$; Resveratrol: $177.50 \pm 12.56 \mathrm{pg} /$ $\mathrm{ml}, \mathrm{P}<0.0001$; Fig. 5B) compared to controls in THP-1 monocytic cells. We also found that NF- $\kappa B$ phosphorylation was induced in a time dependent manner by cell treatment with TNF- $\alpha$ as compared to controls (Fig. 5C). 
Fig. 4. TNF- $\alpha$-induced CCL4 expression is downmodulated by genetic suppression of SAPK/ JNK signaling. THP-1 monocytic cells were transfected with SAPK/JNK siRNA while cells transfected with scrambled siRNA served as mock-treated control as described in materials and methods. Later cells were stimulated with TNF- $\alpha$ and incubated at $37^{\circ} \mathrm{C}$ for $24 \mathrm{hrs}$. Cells and supernatants were collected and CCL4 mRNA in cell lysates and protein expression in culture supernatants were determined using real-time RT-PCR and ELISA, respectively. (A) The data show that SAPK/JNK siRNA transfection in human monocytic cells resulted in significant target gene suppression compared to mock-treated control $(\mathrm{P}=0.0024)$. TNF- $\alpha$ stimulation of THP-1 cells transfected with SAPK/JNK siRNA resulted in significant suppression of CCL4 (B) gene $(\mathrm{P}=0.0108)$ and $(\mathrm{C})$ protein $(\mathrm{P}=0.0151)$ expression compared to mock-treated controls. (D) SAPK/JNK kinase assay confirmed the c-Jun phosphorylation in TNF- $\alpha-$ treated cells compared to mocktreated controls while palmitate

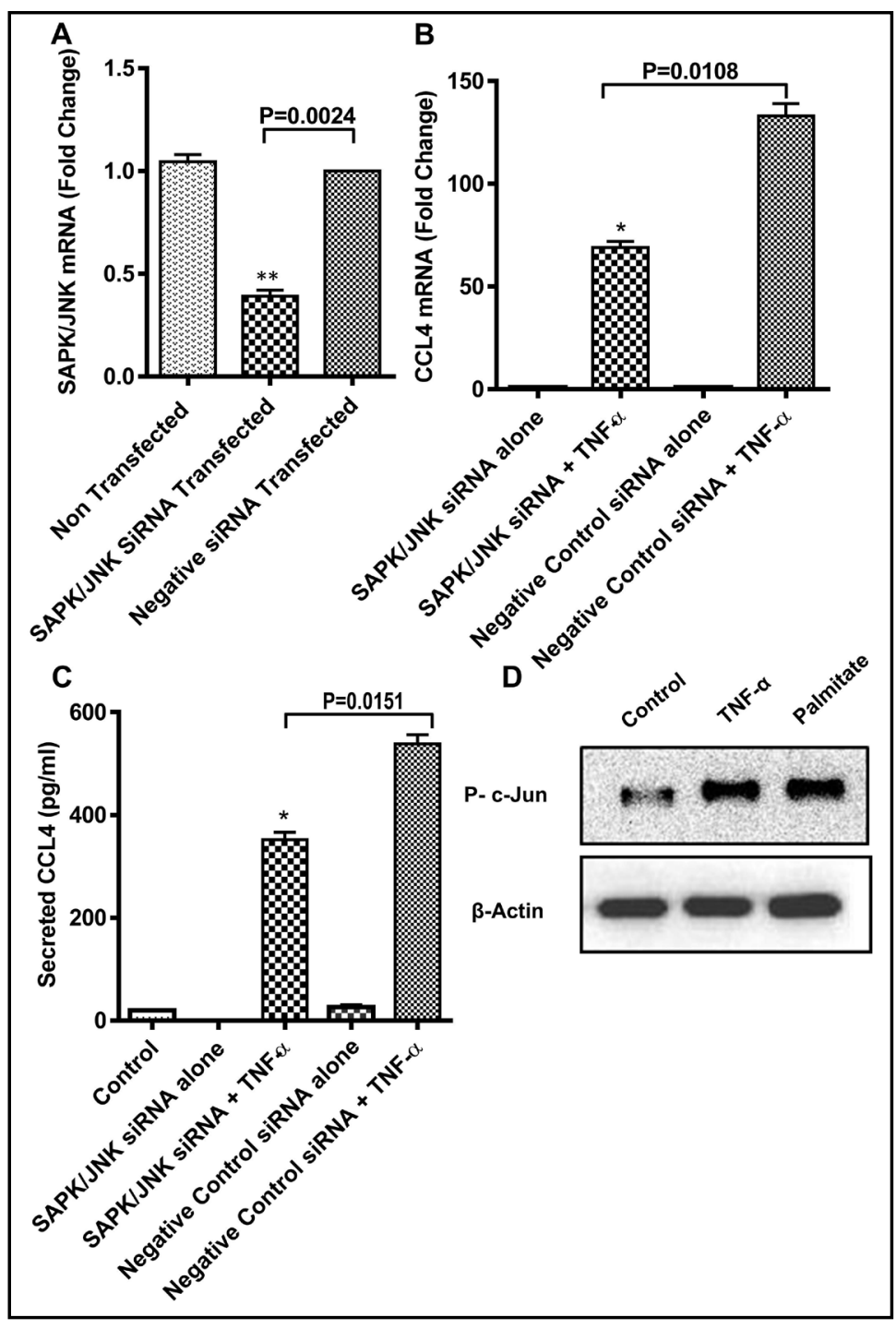
treatment served as a positive control.

\section{TNF- $\alpha$-induced CCL4 expression requires $N F-\kappa B / A P-1$ activation}

It was previously reported that the CCL4 promoter has binding sites for NF- $\kappa B$ and AP-1[48] . Our data show the involvement of NF- $\kappa B$ and MAPK signaling pathways as cells are treated with TNF- $\alpha$ to induce CCL4 expression. We next wanted to know if the TNF- $\alpha$ induced CCL4 expression activated the NF- $\kappa B / A P 1$ activity in THP-1 monocytic cells. To this effect, we used THP-1 X-Blue cells expressing the NF- $\mathrm{KB} / \mathrm{AP}-1$ response element driven SEAP reporter activity upon activation. As expected, TNF- $\alpha$ treatment of THP- 1 X-Blue cells significantly upregulated the NF- $\kappa \mathrm{B} / \mathrm{AP}-1$ activity $(0.95 \pm 0.09 \mathrm{OD})$ compared to controls $(\mathrm{P}=$ 0.0198 ) while LPS treatment served as a positive control (Fig. 6A). This induction of NF- $\mathrm{kB} /$ AP-1 activity corresponded with the increased CCL4 mRNA (91.5 \pm 2.5 fold, $\mathrm{P}=0.0008$; Fig. $6 \mathrm{~B})$ and protein $(303.6 \pm 9.53, \mathrm{P}=0.001$; Fig. $6 \mathrm{C}$ ) expression in these cells, suggesting that TNF- $\alpha$-induced CCL4 expression in monocytic cells implicates the activation of NF- $\kappa B / A P-1$ transcription factors. 
Fig. 5. TNF- $\alpha$-induced CCL4 expression in human monocytic cells is suppressed by NF$\kappa \mathrm{B}$ inhibitors. THP-1 human monocytic cells were pretreated with NF- $\kappa \mathrm{B}$ inhibitors (Triptolide $10 \mu \mathrm{M}$ or Resveratrol $15 \mu \mathrm{M}$ ) for $1 \mathrm{hr}$ and then cells were treated with TNF- $\alpha$ (10ng/ml) for $24 \mathrm{hrs}$. Cells and supernatants were collected and CCL4 mRNA in cell lysates and CCL4 secreted protein expression in culture supernatants were determined using real-time RT-PCR and ELISA, respectively. The data show significant downmodulation of CCL4 (A) gene (Triptolide: $\mathrm{P}<0.0001$; Resveratrol: $\mathrm{P}<0.0001)$ and $(\mathrm{B})$ protein (Triptolide: $\mathrm{P}<0.0001$; Resveratrol: $\mathrm{P}<0.0001)$ expression in cells that were pretreated

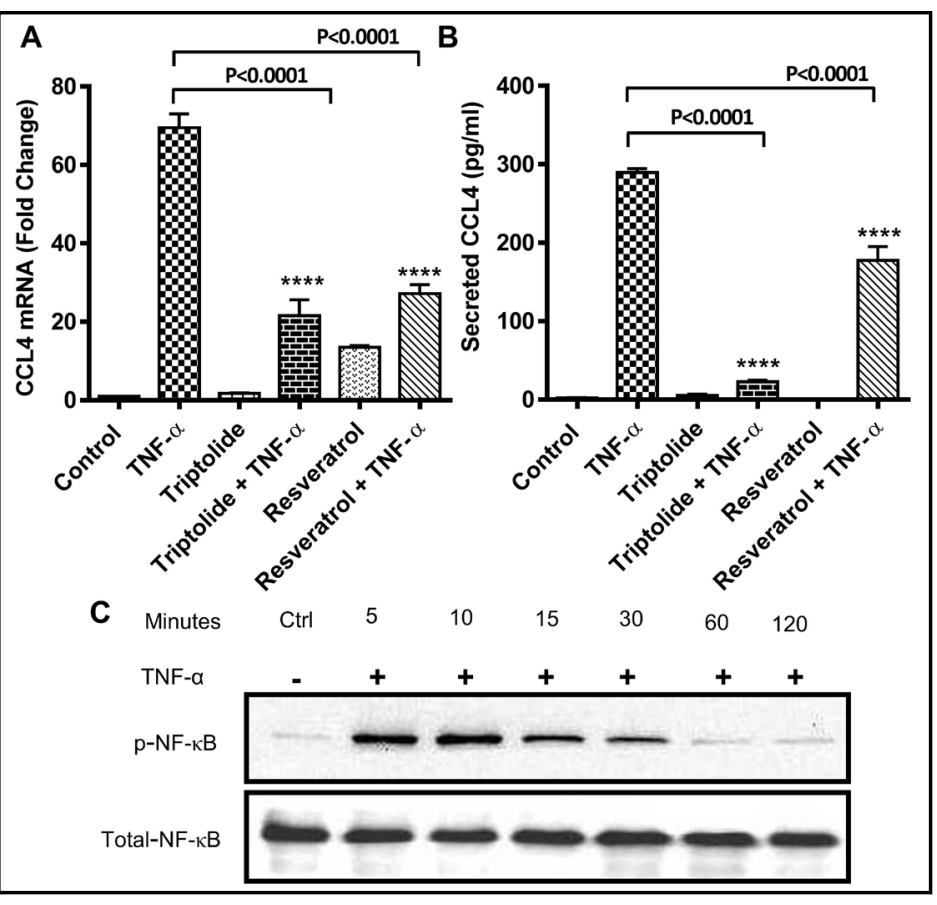
with NF- $\kappa$ B inhibitors compared to mock-treated controls stimulated with TNF- $\alpha$. (C) To analyze TNF- $\alpha$-induced NF- $\kappa$ B phosphorylation, cells were incubated with TNF- $\alpha(10 \mathrm{ng} / \mathrm{ml})$ and cell samples were collected at 5, 10, 15, 30, 60, and 120 min. Mock treated cells served as negative control. Cell lysates in RIPA buffer were calibrated for protein concentration, resolved by SDS-PAGE and NF- $\kappa$ B phosphorylation was assessed by using specific antibodies against phosphorylated and total NF- $\mathrm{KB}$. The blot shows that TNF- $\alpha$ treatment of human monocytic cells induced NF- $\kappa$ B phosphorylation at 5-10 min that reduced thereafter.

\section{Discussion}

The proinflammatory mediators, such as TNF- $\alpha$ and CCL 4 are found to be increased in obesity and/or T2D and are believed to be important actors of metabolic inflammation [4952]. By increasing migration of monocytes into the adipose tissue, CCL4 plays a significant role in metabolic inflammation $[53,54]$. In the present study, we investigated the CCL4 induction in THP-1 monocytic cells and derived macrophages by treatment with TNF- $\alpha$. We show that TNF- $\alpha$, which is one of the most abundant proinflammatory cytokine found in the circulation of obese humans, can induce the expression of CCL4 chemokine in THP-1 human monocytic cells. Likewise, TNF- $\alpha$ also upregulates the expression of CCL4 secretory protein in the THP-1-derived macrophages. This indicates that TNF- $\alpha$ is one of the potential inducers of CCL4 chemokine in monocytes/macrophages. Also, we show that TNF- $\alpha$ driven induction of CCL4 in THP-1 monocytes/macrophages involves signaling through both TNFR1 and TNFR2 receptors on these cells. However, a previous study showed that TNF- $\alpha$ affinity for TNFR1 was higher than its affinity for TNFR2 [32]. Thus, TNF- $\alpha$ interaction, especially with TNFR1, may have direct significance with regard to inflammatory responses. In line with this argument, deletion of TNFR1 was found to be protective against diet-induced obesity in mice through the mechanism that involved increased thermogenesis [55]. We and others have shown high expression of TNF- $\alpha$ receptors in monocytic cells $[47,56]$. It was further shown that TNF- $\alpha$-induced activation of monocytes/macrophages resulted in the expression of inflammatory mediators [47]. Adipose tissue is also an important source of IL-6 which is an important cytokine secreted by macrophages, adipocytes, and other cells including skeletal muscle, fibroblasts, and endothelial cells. We previously reported elevated adipose tissue expression of IL-6/IL-6R as an underlying mechanism of metabolic inflammation in 
Fig. 6. TNF- $\alpha$-driven CCL4 expression in human monocytic cells involves activation of the NF- $\kappa B$ / AP1 activity. THP-1-XBlue cells i.e. THP-1 cells stably expressing a SEAP (secreted embryonic alkaline phosphatase) reporter inducible by NF$\kappa \mathrm{B} / \mathrm{AP}-1$ promoter activity, were incubated with TNF- $\alpha(10 \mathrm{ng} / \mathrm{ml})$ or LPS $(10 \mathrm{ng} / \mathrm{ml}$; positive control) for 24 hrs while mock-treated cells served as negative control. Cell culture media were assayed for SEAP reporter activity (OD detected at $650 \mathrm{~nm}$ wavelength) as a measure of the degree of NF- $\mathrm{BB} / \mathrm{AP}-1$ activation. CCL4 gene expression in THP-1-XBlue cell lysates and CCL4 secreted protein expression in culture supernatants were assessed by real-time RTPCR and ELISA, respectively. The data show (A) significantly enhanced activation of NF$\kappa \mathrm{B} / \mathrm{AP}-1$ activity in THP-1-XBlue cells treated with TNF- $\alpha$ compared to mock-treated control $(\mathrm{P}=0.0198)$. Also, the data show concomitantly upregulated CCL4 (B) gene $(\mathrm{P}=0.0008)$ and $(\mathrm{C})$ secreted protein $(\mathrm{P}=0.001)$ expression in TNF- $\alpha$ stimulated THP-1-XBlue cells compared to mock-treated controls.

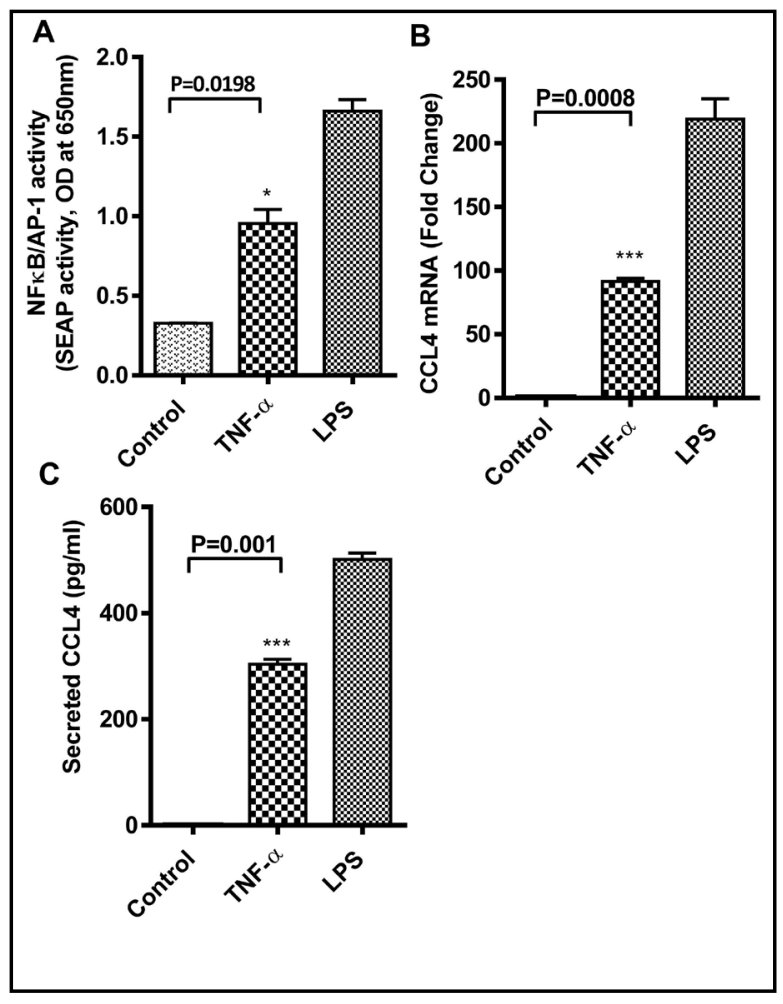

obesity [57]. IL-6 is a systemic regulator of body weight and lipid metabolism [58]. Plasma [39] and adipose tissue [59] levels of IL- 6 were found to correlate with obesity and insulin resistance even better than TNF- $\alpha$. As a myokine, IL- 6 in skeletal muscle acts as an energy sensor by activating AMP-activated protein (AMPK) kinase and increasing glucose disposal, fat oxidation, and lipolysis [60]. IL-6 treatment of mice blunted insulin-stimulated insulin receptor substrate (IRS)-2-associated phosphatidylinositol 3-kinase (PI3K) activity in the liver and also reduced insulin-stimulated glucose uptake in skeletal muscle via defective IRS1-associated PI3K signaling and elevated fatty acyl-CoA levels [61].

Addressing the role of TNFR-mediated signaling in CCL4 production by THP-1 monocytic cells and derived macrophages following treatment with TNF- $\alpha$, the data show that neutralization of TNFR1 and TNFR2 significantly diminished the production of CCL4 by monocytic cells. NF- $\kappa B$ and MAPKs are classical pathways recruited downstream to TNFRmediated signaling. TNF- $\alpha$ activated MAPKs and NF- $\kappa B$ signaling pathways are involved in the regulation of several inflammatory cytokines that contribute to the pathogenesis of different inflammatory conditions. Previous studies have shown that ligation of TNF- $\alpha$ with TNF-R initiates activation of ERK, SAPK/JNK, and p38 MAPK in different cell types [62-64]. Our data show that disruption of SAPK/JNK signaling molecules by specific inhibitors or siRNA significantly blocks TNF- $\alpha$ mediated production of CCL4. We also show that TNF- $\alpha$ induces phosphorylation of the MAPKs including SAPK/JNK and c-Jun. However, MEK/ERK and $\mathrm{p} 38$ MAPK was not found to be involved in this induction which may be due to the reason that these signaling molecules are not involved in CCL4 production by THP- 1 monocytic cells. ERK1/2 and JNK can be activated by a variety of stimuli in various cell types [65]. The present findings are consistent with our previous results showing that activation of MAPKs, except p38 MAPK, was implicated in the expression of MMP-9 in THP-1 human monocytic cells $[66,67]$.

The present data also show that NF- $\kappa \mathrm{B}$ pathway inhibition by Triptolide and Resveratrol significantly down modulates the CCL4 expression in THP-1 monocytic cells at both mRNA and protein levels. This is also consistent with our previous findings of significant suppression in the palmitate-induced MMP-9 expression in human monocytic cells following 
NF- $\kappa B$ pathway inhibition (55). Another study also showed that LPS-induced cytokines/ chemokines gene expression was dependent on the activation of NF- $\mathrm{BB}$ [68]. Activation of NF- $\kappa B$ was found to be responsible, at least in part, for IL-1 $\beta$-induced CCL 4 expression in the human hepatocytes [69]. We further show that TNF- $\alpha$ treatment of THP-1 monocytic cells leads to upregulation of the NF- $\kappa \mathrm{B} / \mathrm{AP}-1$ activity. Taken together, it implies that TNF- $\alpha$ driven CCL4 expression in THP-1 human monocytic cells involves the SAPK/JNK (MAPK) and NF- $\kappa B$ dependent signaling. These data may have pathologic and immunobiological significance of the plausible role of TNF- $\alpha /$ CCL4 axis in metabolic inflammation.

\section{Conclusion}

In summary, data from the present study support the regulatory role of proinflammatory cytokine TNF- $\alpha$ as a driver of CCL4 expression in human monocytic cells and macrophages through the mechanisms that involve SAPK/JNK and NF- $\kappa B$ signaling pathways. These findings unravel new aspects of the inflammatory role of TNF- $\alpha$ through the CCL4 upregulation.

\section{Acknowledgements}

This study was financially supported by Kuwait Foundation for the Advancement of Sciences (KFAS). Grant \# RC14016001 (RA-AM-2017-007 \& RA AM 2016-007).

\section{Disclosure Statement}

The authors declare that they have no competing interests.

\section{References}

1 Maurer M, von Stebut E: Macrophage inflammatory protein-1. Int J Biochem Cell Biol 2004;36:1882-1886.

- 2 Loetscher P, Seitz M, Clark-Lewis I, Baggiolini M, Moser B: Activation of nk cells by cc chemokines. Chemotaxis, ca2+ mobilization, and enzyme release. J Immunol 1996;156:322-327.

3 Taub DD, Sayers TJ, Carter CR, Ortaldo JR: Alpha and beta chemokines induce nk cell migration and enhance nk-mediated cytolysis. J Immunol 1995;155:3877-3888.

4 Menten P, Struyf S, Schutyser E, Wuyts A, De Clercq E, Schols D, Proost P, Van Damme J: The ld78beta isoform of mip-1alpha is the most potent ccr5 agonist and hiv-1-inhibiting chemokine. J Clin Invest 1999;104:R1-5.

5 Berger O, Gan X, Gujuluva C, Burns AR, Sulur G, Stins M, Way D, Witte M, Weinand M, Said J, Kim KS, Taub D, Graves MC, Fiala M: Cxc and cc chemokine receptors on coronary and brain endothelia. Mol Med 1999;5:795-805.

6 Dai YJ, Li YY, Zeng HM, Liang XA, Xie ZJ, Zheng ZA, Pan QH, Xing YX: Effect of pharmacological intervention on mip-1alpha, mip-1 beta and mcp-1 expression in patients with psoriasis vulgaris. Asian Pac J Trop Med 2014;7:582-584.

7 Barczyk A, Pierzchala E, Caramori G, Sozanska E: Increased expression of ccl4/mip-1beta in cd8+ cells and cd4+ cells in sarcoidosis. Int J Immunopathol Pharmacol 2014;27:185-193.

8 Mrugacz M: Ccl4/mip-1beta levels in tear fluid and serum of patients with cystic fibrosis. J Interferon Cytokine Res 2010;30:509-512.

9 Boven LA, Montagne L, Nottet HS, De Groot CJ: Macrophage inflammatory protein-1alpha (mip-1alpha), mip-1beta, and rantes mrna semiquantification and protein expression in active demyelinating multiple sclerosis (ms) lesions. Clin Exp Immunol 2000;122:257-263. 


\section{Cellular Physiology Cell Physiol Biochem 2019;52:908-921 \begin{tabular}{c|c|c|}
\hline DOI: 10.33594/000000063 & (O) 2019 The Author(s). Published by \\
\hline
\end{tabular} and Biochemistry Published online: 10 April 2019 Cell Physiol Biochem Press GmbH\&Co. KG \\ Ahmad et al.: TNF- $\alpha$ Induces CCL4}

- 10 Vila LM, Molina MJ, Mayor AM, Cruz JJ, Rios-Olivares E, Rios Z: Association of serum mip-1alpha, mip1 beta, and rantes with clinical manifestations, disease activity, and damage accrual in systemic lupus erythematosus. Clin Rheumatol 2007;26:718-722.

- 11 Mathews JA, Wurmbrand AP, Ribeiro L, Neto FL, Shore SA: Induction of il-17a precedes development of airway hyperresponsiveness during diet-induced obesity and correlates with complement factor d. Front Immunol 2014;5:440.

- 12 Ryden A, Faresjo M: Altered immune profile from pre-diabetes to manifestation of type 1 diabetes. Diabetes Res Clin Pract 2013;100:74-84.

13 Hanifi-Moghaddam P, Kappler S, Seissler J, Muller-Scholze S, Martin S, Roep BO, Strassburger K, Kolb H, Schloot NC: Diabet Med 2006;23:156-163.

14 DeVries ME, Ran L, Kelvin DJ: On the edge: The physiological and pathophysiological role of chemokines during inflammatory and immunological responses. Semin Immunol 1999;11:95-104.

15 Mirabelli-Badenier M, Braunersreuther V, Viviani GL, Dallegri F, Quercioli A, Veneselli E, Mach F, Montecucco F: Cc and cxc chemokines are pivotal mediators of cerebral injury in ischaemic stroke. Thromb Haemost 2011;105:409-420.

16 Ji Q, Lin Y, Liang Z, Yu K, Liu Y, Fang Z, Liu L, Shi Y, Zeng Q, Chang C, Chai M, Zhou Y: Chemerin is a novel biomarker of acute coronary syndrome but not of stable angina pectoris. Cardiovasc Diabetol 2014;13:145.

- 17 Tatara Y, Ohishi M, Yamamoto K, Shiota A, Hayashi N, Iwamoto Y, Takeda M, Takagi T, Katsuya T, Ogihara T, Rakugi H: Macrophage inflammatory protein-1beta induced cell adhesion with increased intracellular reactive oxygen species. J Mol Cell Cardiol 2009;47:104-111.

18 Weisberg SP, McCann D, Desai M, Rosenbaum M, Leibel RL, Ferrante AW Jr.: Obesity is associated with macrophage accumulation in adipose tissue. J Clin Invest 2003;112:1796-1808.

19 Gustafson B, Hammarstedt A, Andersson CX, Smith U: Inflamed adipose tissue: A culprit underlying the metabolic syndrome and atherosclerosis. Arterioscler Thromb Vasc Biol 2007;27:2276-2283.

20 Kanda H, Tateya S, Tamori Y, Kotani K, Hiasa K, Kitazawa R, Kitazawa S, Miyachi H, Maeda S, Egashira K, Kasuga M: Mcp-1 contributes to macrophage infiltration into adipose tissue, insulin resistance, and hepatic steatosis in obesity. J Clin Invest 2006;116:1494-1505.

21 Weisberg SP, Hunter D, Huber R, Lemieux J, Slaymaker S, Vaddi K, Charo I, Leibel RL, Ferrante AW Jr.: Ccr2 modulates inflammatory and metabolic effects of high-fat feeding. J Clin Invest 2006;116:115-124.

22 Benoist C, Mathis D: Cell death mediators in autoimmune diabetes--no shortage of suspects. Cell 1997;89:1-3.

23 Hernandez-Trejo M, Montoya-Estrada A, Torres-Ramos Y, Espejel-Nunez A, Guzman-Grenfell A, MoralesHernandez R, Tolentino-Dolores M, Laresgoiti-Servitje E: Oxidative stress biomarkers and their relationship with cytokine concentrations in overweight/obese pregnant women and their neonates. BMC Immunol 2017;18:3.

24 Dahlman I, Kaaman M, Olsson T, Tan GD, Bickerton AS, Wahlen K, Andersson J, Nordstrom EA, Blomqvist L, Sjogren A, Forsgren M, Attersand A, Arner P: A unique role of monocyte chemoattractant protein 1 among chemokines in adipose tissue of obese subjects. J Clin Endocrinol Metab 2005;90:5834-5840.

25 Boden G: Obesity and free fatty acids. Endocrinol Metab Clin North Am 2008;37:635-646, viii-ix.

- 26 Mirza S, Hossain M, Mathews C, Martinez P, Pino P, Gay JL, Rentfro A, McCormick JB, Fisher-Hoch SP: Type 2-diabetes is associated with elevated levels of tnf-alpha, il-6 and adiponectin and low levels of leptin in a population of mexican americans: A cross-sectional study. Cytokine 2012;57:136-142.

27 Hotamisligil GS, Spiegelman BM: Tumor necrosis factor alpha: A key component of the obesity-diabetes link. Diabetes 1994;43:1271-1278.

28 Aggarwal BB, Natarajan K: Tumor necrosis factors: Developments during the last decade. Eur Cytokine Netw 1996; 7:93-124.

29 Kern PA, Saghizadeh M, Ong JM, Bosch RJ, Deem R, Simsolo RB: The expression of tumor necrosis factor in human adipose tissue. Regulation by obesity, weight loss, and relationship to lipoprotein lipase. J Clin Invest 1995;95:2111-2119.

30 Hotamisligil GS, Arner P, Caro JF, Atkinson RL, Spiegelman BM: Increased adipose tissue expression of tumor necrosis factor-alpha in human obesity and insulin resistance. J Clin Invest 1995;95:2409-2415.

31 Saghizadeh M, Ong JM, Garvey WT, Henry RR, Kern PA: The expression of tnf alpha by human muscle. Relationship to insulin resistance. J Clin Invest 1996;97:1111-1116. 


\section{Cellular Physiology Cell Physiol Biochem 2019;52:908-921 \begin{tabular}{c|c|c|}
\hline DOI: 10.33594/000000063 & (O) 2019 The Author(s). Published by \\
\hline
\end{tabular} and Biochemistry Published online: 10 April 2019 Cell Physiol Biochem Press GmbH\&Co. KG \\ Ahmad et al.: TNF- $\alpha$ Induces CCL4}

- 32 Grell M, Wajant H, Zimmermann G, Scheurich P: The type 1 receptor (cd120a) is the high-affinity receptor for soluble tumor necrosis factor. Proc Natl Acad Sci U S A 1998;95:570-575.

- 33 Faustman DL: Tnf, tnf inducers, and tnfr2 agonists: A new path to type 1 diabetes treatment. Diabetes Metab Res Rev 2018; DOI:10.1002/dmrr.2941.

- 34 Sabio G, Davis RJ: Tnf and map kinase signalling pathways. Semin Immunol 2014;26:237-245.

- 35 Winston BW, Lange-Carter CA, Gardner AM, Johnson GL, Riches DW: Tumor necrosis factor alpha rapidly activates the mitogen-activated protein kinase (mapk) cascade in a mapk kinase kinase-dependent, c-raf-1independent fashion in mouse macrophages. Proc Natl Acad Sci U S A 1995;92:1614-1618.

36 Mishima Y, Kuyama A, Tada A, Takahashi K, Ishioka T, Kibata M: Relationship between serum tumor necrosis factor-alpha and insulin resistance in obese men with type 2 diabetes mellitus. Diabetes Res Clin Pract 2001;52:119-123.

37 Katsuki A, Sumida Y, Murashima S, Murata K, Takarada Y, Ito K, Fujii M, Tsuchihashi K, Goto H, Nakatani $\mathrm{K}$, Yano Y: Serum levels of tumor necrosis factor-alpha are increased in obese patients with noninsulindependent diabetes mellitus. J Clin Endocrinol Metab 1998;83:859-862.

38 Zinman B, Hanley AJ, Harris SB, Kwan J, Fantus IG: Circulating tumor necrosis factor-alpha concentrations in a native canadian population with high rates of type 2 diabetes mellitus. J Clin Endocrinol Metab 1999;84:272-278.

- 39 Kern PA, Ranganathan S, Li C, Wood L, Ranganathan G: Adipose tissue tumor necrosis factor and interleukin-6 expression in human obesity and insulin resistance. Am J Physiol Endocrinol Metab 2001;280:E745-751.

- 40 Nielsen ST, Lehrskov-Schmidt L, Krogh-Madsen R, Solomon TP, Lehrskov-Schmidt L, Holst JJ, Moller K: Tumour necrosis factor-alpha infusion produced insulin resistance but no change in the incretin effect in healthy volunteers. Diabetes Metab Res Rev 2013;29:655-663.

41 Sjoholm A, Nystrom T: Inflammation and the etiology of type 2 diabetes. Diabetes Metab Res Rev 2006;22:4-10.

42 Rabinovitch A: An update on cytokines in the pathogenesis of insulin-dependent diabetes mellitus. Diabetes Metab Rev 1998;14:129-151.

43 Hotamisligil GS, Shargill NS, Spiegelman BM: Adipose expression of tumor necrosis factor-alpha: Direct role in obesity-linked insulin resistance. Science 1993;259:87-91.

$44 \mathrm{Xu} \mathrm{H}$, Uysal KT, Becherer JD, Arner P, Hotamisligil GS: Altered tumor necrosis factor-alpha (tnf-alpha) processing in adipocytes and increased expression of transmembrane tnf-alpha in obesity. Diabetes 2002;51:1876-1883.

- 45 Kochumon S, Wilson A, Chandy B, Shenouda S, Tuomilehto J, Sindhu S, Ahmad R: Palmitate activates ccl4 expression in human monocytic cells via tlr4/myd88 dependent activation of nf-kappab/mapk/ pi3k signaling systems. Cell Physiol Biochem 2018;46:953-964.

- 46 Miyazaki Y, Pipek R, Mandarino LJ, DeFronzo RA: Tumor necrosis factor alpha and insulin resistance in obese type 2 diabetic patients. Int J Obes Relat Metab Disord 2003;27:88-94.

47 Ahmad R, Al-Roub A, Kochumon S, Akther N, Thomas R, Kumari M, Koshy MS, Tiss A, Hannun YA, Tuomilehto J, Sindhu S, Rosen ED: The synergy between palmitate and tnf-alpha for ccl2 production is dependent on the trif/irf3 pathway: Implications for metabolic inflammation. J Immunol 2018;200:35993611.

48 Gonsalves C, Kalra VK: Endothelin-1-induced macrophage inflammatory protein-1beta expression in monocytic cells involves hypoxia-inducible factor- 1 alpha and ap- 1 and is negatively regulated by microrna-195. J Immunol 2010;185:6253-6264.

49 Makki K, Froguel P, Wolowczuk I: Adipose tissue in obesity-related inflammation and insulin resistance: Cells, cytokines, and chemokines. ISRN Inflamm 2013;2013:139239.

- 50 Borges MD, Franca EL, Fujimori M, Silva SMC, de Marchi PGF, Deluque AL, Honorio-Franca AC, de Abreu LC: Relationship between proinflammatory cytokines/chemokines and adipokines in serum of young adults with obesity. Endocr Metab Immune Disord Drug Targets 2018;18:260-267.

- 51 Ota T: Chemokine systems link obesity to insulin resistance. Diabetes Metab J 2013;37:165-172.

- 52 Sindhu S, Akhter N, Arefanian H, Al-Roub AA, Ali S, Wilson A, Al-Hubail A, Al-Beloushi S, Al-Zanki S, Ahmad R: Increased circulatory levels of fractalkine (cx3cl1) are associated with inflammatory chemokines and cytokines in individuals with type-2 diabetes. J Diabetes Metab Disord 2017;16:15. 


\section{Cellular Physiology Cell Physiol Biochem 2019;52:908-921

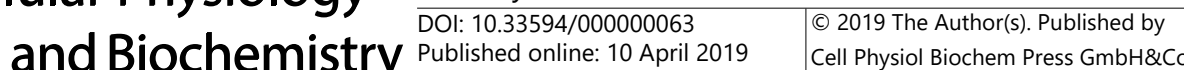 \\ Ahmad et al.: TNF- $\alpha$ Induces CCL4}

- 53 Surmi BK, Hasty AH: The role of chemokines in recruitment of immune cells to the artery wall and adipose tissue. Vascul Pharmacol 2010;52:27-36.

- 54 von Stebut E, Metz M, Milon G, Knop J, Maurer M: Early macrophage influx to sites of cutaneous granuloma formation is dependent on mip-1alpha /beta released from neutrophils recruited by mast cell-derived tnfalpha. Blood 2003;101:210-215.

- 55 Romanatto T, Roman EA, Arruda AP, Denis RG, Solon C, Milanski M, Moraes JC, Bonfleur ML, Degasperi GR, Picardi PK, Hirabara S, Boschero AC, Curi R, Velloso LA: Deletion of tumor necrosis factor-alpha receptor 1 (tnfr1) protects against diet-induced obesity by means of increased thermogenesis. J Biol Chem 2009;284:36213-36222.

56 Calvano SE, van der Poll T, Coyle SM, Barie PS, Moldawer LL, Lowry SF: Monocyte tumor necrosis factor receptor levels as a predictor of risk in human sepsis. Arch Surg 1996;131:434-437.

57 Sindhu S, Thomas R, Shihab P, Sriraman D, Behbehani K, Ahmad R: Obesity is a positive modulator of il-6r and il-6 expression in the subcutaneous adipose tissue: Significance for metabolic inflammation. PLoS One 2015;10:e0133494.

- 58 Shoelson SE, Lee J, Goldfine AB: Inflammation and insulin resistance. J Clin Invest 2006;116:1793-1801.

- 59 Bastard JP, Jardel C, Bruckert E, Blondy P, Capeau J, Laville M, Vidal H, Hainque B: Elevated levels of interleukin 6 are reduced in serum and subcutaneous adipose tissue of obese women after weight loss. J Clin Endocrinol Metab 2000;85:3338-3342.

60 Hoene M, Weigert C: The role of interleukin-6 in insulin resistance, body fat distribution and energy balance. Obes Rev 2008;9:20-29.

- 61 Kim HJ, Higashimori T, Park SY, Choi H, Dong J, Kim YJ, Noh HL, Cho YR, Cline G, Kim YB, Kim JK: Differential effects of interleukin-6 and -10 on skeletal muscle and liver insulin action in vivo. Diabetes 2004;53:10601067.

62 Winston BW, Chan ED, Johnson GL, Riches DW: Activation of p38mapk, mkk3, and mkk4 by tnf-alpha in mouse bone marrow-derived macrophages. J Immunol 1997;159:4491-4497.

63 Song HY, Regnier CH, Kirschning CJ, Goeddel DV, Rothe M: Tumor necrosis factor (tnf)-mediated kinase cascades: Bifurcation of nuclear factor-kappab and c-jun n-terminal kinase (jnk/sapk) pathways at tnf receptor-associated factor 2. Proc Natl Acad Sci U S A 1997;94:9792-9796.

64 Chan ED, Winston BW, Jarpe MB, Wynes MW, Riches DW: Preferential activation of the p46 isoform of jnk/ sapk in mouse macrophages by tnf alpha. . Proc Natl Acad Sci U S A 1997;94:13169-13174.

65 Firestein GS, Manning AM: Signal transduction and transcription factors in rheumatic disease. Arthritis Rheum 1999;42:609-621.

- 66 Sindhu S, Al-Roub A, Koshy M, Thomas R, Ahmad R: Palmitate-induced mmp-9 expression in the human monocytic cells is mediated through the tlr4-myd88 dependent mechanism. Cell Physiol Biochem 2016;39:889-900.

- 67 Al-Rashed F, Kochumon S, Usmani S, Sindhu S, Ahmad R: Pam3csk4 induces mmp-9 expression in human monocytic thp-1 cells. Cell Physiol Biochem 2017;41:1993-2003.

- 68 Guijarro-Munoz I, Compte M, Alvarez-Cienfuegos A, Alvarez-Vallina L, Sanz L: Lipopolysaccharide activates toll-like receptor 4 (tlr4)-mediated nf-kappab signaling pathway and proinflammatory response in human pericytes. J Biol Chem 2014;289:2457-2468.

69 Zhang T, Guo CJ, Li Y, Douglas SD, Qi XX, Song L, Ho WZ: Interleukin-1beta induces macrophage inflammatory protein-1beta expression in human hepatocytes. Cell Immunol 2003;226:45-53. 